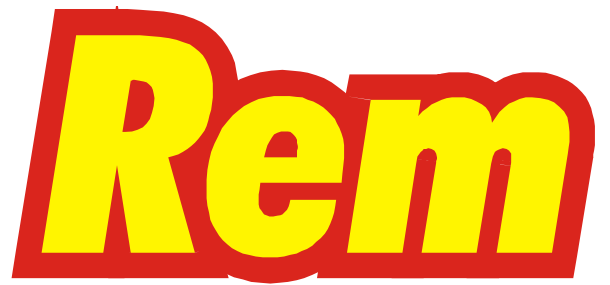

REM - Revista Escola de Minas

Afiliada à: Associação Brasileira de Editores Científicos

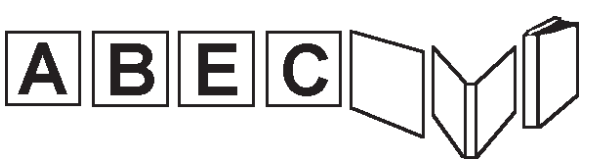

A REM está indexada no Scielo

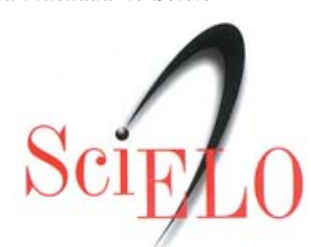

www.scielo.br

\section{Carta do Editor}

Numa página interna, publicamos a primeira página da REM, na qual aparecem os estudantes que, em 1936, tiveram a idéia de criar uma revista, bem como a puseram em prática. As correspondências dos dois primeiros dirigentes da REM, publicadas no primeiro número desse ano, enchem de orgulho a equipe atual da revista.

Tive o prazer de conviver e partilhar da amizade de alguns desses homens, que deixaram sua marca no setor mínero-metalúrgico brasileiro: Sílvio Vilar Guedes, Walter José Von Krüger, Amaro Lanari Júnior, etc.

O empreendimento desse grupo de estudantes, que, por muitos anos, foi seguido por outros, talvez nos ajude a compreender a força que a Escola de Minas manteve durante muitos anos. À criação da REM se seguiu a da SEE (Sociedade Excursionista Espeleológica), mais tarde a da SICEG (Sociedade de Intercâmbio e Estudos Geológicos) e de suas co-irmãs SICEM, SEMINAS, etc.

Também pelas páginas da REM passaram homens que deixaram sua marca no setor na qual ela se insere, homens como Octávio Barbosa, Victor Dequech, Djalma Guimarães, Glycon de Paiva, Luciano Jacques de Moraes, Borisa Cimbleris, Licínio Barbosa e tantos outros. Isso só aumenta a responsabilidade dos atuais dirigentes da REM.

Por motivo de força maior, estamos substituindo dois dos nossos editores: Ricardo Silveira (realizando pós-doutorado nos Estados Unidos) e Fernando Gabriel (que assumiu a coordenação da REDEMAT). Ambos foram de fundamental importância nas mudanças que efetuamos na revista, bem como na implantação do SEER. A escolha dos professores Marcílio Sousa da Rocha Freitas (Civil) e Adilson Rodrigues da Costa (Metalurgia \& Materiais), para substituí-los como novos editores adjuntos, levou em consideração a atuação e o alto conceitos que ambos gozam nas respectivas áreas em que atuam.

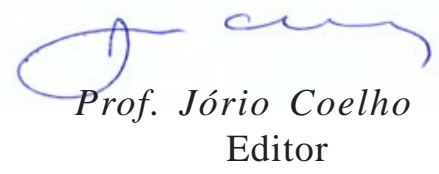

